Eleventh Floor, Menzies Building

Monash University, Wellington Road

CLAYTON Vic 3800 AUSTRALIA

Telephone:

(03) 9905 2398, (03) 99055112

Fax:

(03) 99052426

e-mail:

Internet home page: from overseas:

61399052398 or

61399055112

61399052426

impact@buseco.monash.edu.au http//www.monash.edu.au/policy/

\title{
The Long-Run Effects of Structural Change and the Treatment of International Capital Accumulation, Mobility and Ownership
}

by

George VERIKIOS

Centre of Policy Studies

Monash University

And

Kevin HANSLOW

Centre for International Economics

Sydney

General Paper No. G-179 January 2009 



\title{
THE LONG-RUN EFFECTS OF STRUCTURAL CHANGE AND
}

\section{THE TREATMENT OF INTERNATIONAL CAPITAL}

\section{ACCUMULATION, MOBILITY AND OWNERSHIP}

\author{
George Verikios \\ Centre of Policy Studies, Monash University, Clayton, Victoria, Australia 3800. \\ Kevin Hanslow \\ Centre for International Economics, Sydney, New South Wales, Australia 2001.
}

\begin{abstract}
$\underline{\text { Abstract }}$
Taking a commonly-used and commonly-available trade policy model as our starting point, we examine the long-run effects of large-scale structural change with and without international capital accumulation, mobility and ownership. We demonstrate the relative merits and limitations of different treatments of international capital accumulation, mobility and ownership. In doing so, we present a treatment of international capital accumulation, mobility and ownership that gives policy analysts an approach to analysing the effects of large-scale structural policies that is not too heavy in its theoretical and data demands. Our findings support the work of Baldwin (1992) and others who have demonstrated that ignoring capital accumulation, mobility and ownership underestimates net output and welfare effects of large-scale structural change.
\end{abstract}

JEL codes: $\quad$ C68, F15, F21.

Keywords: computable general equilibrium models, capital accumulation, international capital mobility and ownership, structural change.

\section{Acknowledgements}

Most of the work reported here was undertaken while both authors were at the Productivity Commission, Australia. The views expressed here are ours and do not necessarily represent those of Monash University or the Centre for International Economics. We thank Philippa Dee for helpful comments on this work. 


\section{Table of contents}

1. Introduction 1

2. The models 4

2.1 GTAP 4

2.1.1 A linear equation system 4

2.1.2 GTAP capital theory 6

2.2 GTAP with international capital mobility 8

2.2.1 Modifications to the GTAP theoretical structure 8

2.2.2 Modifications to the GTAP base data 11

2.2.3 Model closure 12

2.2.4 Regional and sectoral detail 13

3. Implementing the Uruguay Round 14

$\begin{array}{lll}3.1 & \text { Import tariffs } & 14\end{array}$

3.2 Export subsidies $\quad 15$

3.3 Output subsidies 16

\begin{tabular}{ll}
3.4 & The Multifibre Agreement \\
\hline
\end{tabular}

4. Results 18

4.1 Scenario 1: GTAP 18

4.2 Scenario 2: GTAP with endogenous regional capital stocks 22

4.3 Scenario 3: GTAPICM with perfect capital mobility 25

4.4 Scenario 4: GTAPICM with imperfect capital mobility 28

5. Concluding remarks 30

References 33

\section{Tables}

1 Average reduction in ad valorem tariff rates by region, weighted by the ex-duty value of imports 15

2 Average reduction in ad valorem export subsidy rates by region, weighted by $\begin{array}{ll}\text { the value of exports at domestic (pre-subsidy) prices } & 16\end{array}$

3 Average reduction in ad valorem output subsidies by region, weighted by the $\begin{array}{ll}\text { value of output at producers' (pre-subsidy) prices } & 17\end{array}$

$4 \quad$ Average bilateral MFA ad valorem export tax rates in GTAP 4, weighted by $\begin{array}{lr}\text { the value of exports at f.o.b. prices } & 18\end{array}$

$5 \quad$ The effects of UR implementation using GTAP 21

6 The effects of UR implementation using GTAP with endogenous regional capital stocks

7 The effects of UR implementation using GTAPICM with perfect capital $\begin{array}{ll}\text { mobility } & 27\end{array}$

8 The effects of UR implementation using GTAPICM with imperfect capital mobility 


\section{Introduction}

Large-scale structural policies (such as multilateral trade liberalisation) cause significant long-run effects including the long-run reallocation of capital between industries and economies (Krugman and Obstfeld 2003). Baldwin (1992) has formally demonstrated, both theoretically and empirically, that capital accumulation can dominate the effects of trade liberalisation on net output; this work applied a stylised framework with intertemporal optimisation. ${ }^{1}$ Willenbockel (1999) extends this stylised framework by adding cross-border ownership of physical capital, which allows a more rigorous examination of the effects of capital accumulation and reallocation from trade liberalisation upon welfare. Together, these studies establish the importance of modelling capital accumulation, reallocation and ownership when analysing the long-run effects of large-scale structural policies.

As is usually observed in economics, and observed by Willenbockel (1999), the applied trade policy modelling literature has not yet caught up with the theoretical and applied-theoretic work discussed above. That is, for the most part, the typical analytical framework in applied trade policy modelling either ignores the issue of capital accumulation and mobility or, it implements it in a way that ignores the issue of cross-border ownership of physical capital. The GTAP model (Hertel and Tsigas 1997) is one of the most commonly-used models, if not the most commonly-used model, ${ }^{2}$ in quantifying the effects of large-scale structural policies. ${ }^{3}$ It suffers from the limitation of ignoring the issue of capital accumulation and mobility altogether despite the fact that it has been specifically developed for analysing global trade and industry policies.

\footnotetext{
${ }^{1}$ Others who have also explored this issue are Smith $(1976,1977)$ and Srinivasan and Bhagwati (1980).

2 Another commonly-used global model is G-Cubed (McKibbin and Wilcoxen 1999). A recent search on Google Scholar for the term "GTAP" resulted in 8,110 matches whereas for the term "G-Cubed" resulted in 1,390 matches.

${ }^{3}$ For some examples, see Adams (2005); Anderson et al. (2006); Anderson and Pangestu (1998); Brockmeier and Pelikan (2008); Domingues et al. (2008); Elbehri et al. (2000); Fernandez de Cordoba et al. (2005); Fugazza and Vanzetti (2008); Islam (2003); Nijkamp et al. (2005).
} 
Walmsley (2002) represents the only study (that we are aware of) that addresses the capital accumulation and mobility limitations of GTAP. ${ }^{4}$ It does so by defining and tracking crossborder bilateral ownership of all endowments, including physical capital, in GTAP. In this respect, it represents the gold standard in the applied trade policy modelling literature by matching the advanced stylised framework developed by Willenbockel (1999). But the limitations of such an approach are that it requires a heavy investment in terms of theoretical rigour and an even heavier investment in terms of data.

A less advanced approach is that taken by Francois et al. (1995), which analyses a largescale structural policy using three treatments of capital accumulation: (i) no capital accumulation (the typical treatment); (ii) capital accumulation funded exclusively from domestic saving with a fixed saving rate; (iii) capital accumulation funded exclusively from domestic saving with an endogenous saving rate. In none of the three treatments is capital mobile between regions. This approach is an attempt to address the importance of capital accumulation effects of trade liberalisation on net output. The advantages of this approach are that it requires only model closure changes to move away from the typical treatment of (no) capital accumulation, and no extra investment in data is required.

There is an alternative approach to modelling capital accumulation, mobility and ownership that predates and represents a middle ground between the subsequent treatments of Francois et al. (1995) on the one hand, and Walmsley (2002) and Willenbockel (1999) on the other. The alternative is that taken by the SALTER model (Jomini et al. 1994), which was the GTAP model's precursor. Here we present the SALTER treatment of international capital mobility

\footnotetext{
4 Here we are referring to the standard GTAP model as documented in Hertel and Tsigas (1997), which is comparative-static. The Dynamic GTAP model (Ianchovichina and McDougall 2000) is a recursively-dynamic model that addresses the capital accumulation and mobility limitations of the standard GTAP model.
} 
(McDougall 1993) and apply it to GTAP, which we term GTAPICM: GTAP with International Capital Mobility. ${ }^{5}$

In presenting the SALTER treatment of international capital mobility, we apply a largescale structural policy - the Uruguay Round of trade negotiations (UR) ${ }^{6}$ - using four treatments: (i) no capital accumulation and no capital mobility (standard GTAP); (ii) capital accumulation and perfect international capital mobility with no cross-border ownership of capital (GTAP with endogenous regional capital stocks); ${ }^{7}$ (iii) capital accumulation and perfect international capital mobility with net cross-border ownership of capital; ${ }^{8}$ and (iv) capital accumulation and imperfect international capital mobility with net cross-border ownership of capital. ${ }^{9}$ We thus move systematically from the typical approach in trade policy modelling to an approach that moves a long way towards the gold standard of Walmsley (2002).

In presenting the SALTER treatment of international capital accumulation, mobility and ownership, we address one of our main objectives: to outline a treatment of international capital accumulation, mobility and ownership that gives applied trade policy practitioners a middle approach to analysing the effects of large-scale structural policies. That is, regional capital accumulation (as in Francois et al. (1995) and Walmsley (2002)) with cross-border capital ownership (as in Walmsley (2002) but absent in Francois et al. (1995)), thus allowing changes in regional welfare due to structural changes to be accurately tracked. Although the approach

5 The SALTER treatment of international capital mobility has never been presented in an academic journal publication. Thus, one objective of this paper is to introduce the SALTER treatment to applied trade policy practitioners and make it more widely known.

6 The UR can be regarded as a large-scale structural policy: it was a significant first step towards capping the level of protection for agriculture, manufacturing, services and intellectual property to the status quo of the early 1990s, while also committing contracting parties to significant liberalisation in manufacturing and agriculture.

7 This is the approach taken in Adams (2005).

8 This treatment allows regions to fund growth in their capital stock using domestic saving and foreign borrowing, and allows full arbitrage of regional rates of return. It is similar to the 'long-run closure with the steady-state database' in Walmsley (2002).

9 This treatment forces all capital stock growth in a given region to be funded by saving only from within the region itself. This is similar to the 'endogenous capital, fixed savings rate' treatment in Francois et al. (1995) but without international capital mobility and cross-border ownership of capital. 
allows changes in regional welfare to be accurately tracked, it does not require the high theoretical and data demands that come with tracking bilateral ownership of capital as in Walmsley (2002).

In applying a large-scale structural policy using four treatments of capital accumulation, mobility and ownership, we address another one of our main objectives: to demonstrate to applied trade policy practitioners the relative merits and limitations of different treatments of international capital accumulation, mobility and ownership using a widely-used and widelyavailable trade policy model and a single, consistent experiment. ${ }^{10}$ The work of Baldwin (1992) and others suggests that the relevant metrics in this regard are the qualitative and quantitative effects on (i) capital stocks, (ii) net output, and (iii) welfare. We apply these metrics here in assessing the relative merits and limitations of different treatments of international capital accumulation, mobility and ownership.

\section{The models}

\subsection{GTAP}

\subsubsection{A linear equation system}

The UR experiment is first conducted with the GTAP model: a multi-regional CGE model of world trade and investment that represents markets as perfectly competitive, industry technologies as linearly homogeneous, and traded goods as imperfectly substitutable. ${ }^{11}$ The defining characteristic of CGE models is a comprehensive representation of the economy, i.e., as a complete system of interdependent components: industries, households, investors, governments, importers and exporters (Dixon et al. 1992).

\footnotetext{
${ }^{10}$ In this respect, the work of Francois et al. (1995) makes a similar contribution but only addresses the issue of capital accumulation; it does not address the issues of capital mobility and ownership. It also does not apply a widely-used and widely-available trade policy model.
} 
Formally, GTAP is represented by equations specifying behavioural and definitional relationships. There are $m$ such relationships involving a total of $p$ variables and these can be compactly written in matrix form as

$$
A v=\mathbf{0},
$$

where $A$ is an $m \times p$ matrix of coefficients, $v$ is a $p \times 1$ vector of percentage changes in model variables and $\mathbf{0}$ is a $p \times 1$ null vector. Of the $p$ variables, $e$ are exogenous (e.g., tariffs, technology, preferences, etc). The $e$ variables can be used to shock the model to simulate changes in the $(p-e)$ endogenous variables. Many of the functions underlying (1) are highly nonlinear. Writing the equation system like (1) allows us to avoid finding the explicit forms for the nonlinear functions and we can therefore write percentage changes (or changes) in the $(p-e)$ variables as linear functions of the percentage changes (or changes) in the $e$ variables. To do this, we rearrange (1) as

$$
A_{n} \boldsymbol{n}+A_{x} \boldsymbol{x}=\mathbf{0},
$$

where $\boldsymbol{n}$ and $\boldsymbol{x}$ are vectors of percentage changes in endogenous and exogenous variables. $A_{n}$ and $A_{x}$ are matrices formed by selecting columns of $A$ corresponding to $\boldsymbol{n}$ and $\boldsymbol{x}$. If $A_{n}$ is square and nonsingular, we can compute percentage changes in the endogenous variables as

$$
\boldsymbol{n}=-A_{n}^{-1} A_{x} \boldsymbol{x} .
$$

Computing solutions to an economic model using (2) and assuming the coefficients of the $A$ matrices are constant is the method pioneered by Johansen (1960).

Equations (1) represent the percentage-change forms of the nonlinear functions underlying the model; these forms are derived by total differentiation. Thus, (1) is an approximation based on marginal changes in the independent variables. So (2) only provides an approximate solution

11 This is version 4.1, which is available at https://www.gtap.agecon.purdue.edu/resources/res_display.asp? RecordID=415 and is extensively documented in Hertel and Tsigas (1997). 
to the endogenous variables $\boldsymbol{n}$; for marginal changes in $\boldsymbol{x}$ the approximation is accurate but for discrete changes in $\boldsymbol{x}$ the approximation will be inaccurate. The problem of accurately calculating $\boldsymbol{n}$ for large changes in $\boldsymbol{x}$ is equivalent to allowing the coefficients of the $A$ matrices to be nonconstant. The problem is solved by breaking the change in $\boldsymbol{x}$ into $\boldsymbol{i}$ equal percentage changes. The multistep solution procedure requires that there are $(i-1)$ intermediate values of the underlying (levels) values of $\boldsymbol{n}$, i.e., $\boldsymbol{N}$. The intermediate values of $\boldsymbol{N}$ are obtained by successively updating the values of $\boldsymbol{N}$ after each of the $i$ steps is applied. Once the values of $\boldsymbol{N}$ are updated for any given step, the coefficients of the $\boldsymbol{A}$ matrices in (2) are recomputed before (2) is solved again. ${ }^{12}$

\subsubsection{GTAP capital theory}

Here we describe some of the key features of the theoretical structure of GTAP and also present the model equations that relate to the treatment of capital; the complete model equation system is documented in Hertel and Tsigas (1997).

The GTAP closure adopted here is typical. It fixes all technical change variables and all rates of tax and subsidy. Further, it fixes the level of factor endowments in each region, i.e., land, skilled labour, unskilled labour, capital and natural resources. Thus, the prices of all factors in each region are free to vary. At the industry level, land is mobile between industries to a very limited extent and natural resources are effectively fixed for each industry. Capital and (skilled and unskilled) labour are perfectly mobile between industries within a given region. Investment moves between regions so as to equilibrate the expected rate of return on capital across the $r$ regions $\left(R E_{r}\right)$ :

\footnotetext{
12 The models applied here are implemented and solved using the multistep algorithms available in the GEMPACK economic modelling software (Harrison and Pearson 1996).
} 


$$
R E_{r}=R E,
$$

where $R E$ is the global expected rate of return on capital, and

$$
R E_{r}=\frac{R C_{r}}{\left(\frac{K E_{r}}{K B_{r}}\right)^{\rho}} .
$$

$R C_{r}$ is the current rate of return in region $r$ and is defined as the ratio of the rental price of capital and the price of investment. $K B_{r}$ is the beginning-of-period capital stock in region $r$ and $K E_{r}$ is the end-of-period capital stock in region $r$, defined by the accumulation equation

$$
K E_{r}=K B_{r}(1-\delta)+Q I_{r},
$$

where $\delta$ is the depreciation rate and $Q I_{r}$ is the volume of investment in $r$ during the simulation period.

Thus, equation (4) sets $R E_{r}$ equal to $R C_{r}$ unless $K E_{r}$ diverges from $K B_{r}$. Where $\left(\frac{K E_{r}}{K B_{r}}\right) \neq 1$, then $R E_{r}$ will diverge from $R C_{r}$ depending on the size of the positive parameter $\rho$.

Despite the equalisation of $R E_{r}$ across regions, firm's production decisions are based on $K B_{r}$. As $K B_{r}$ is exogenous, capital stocks are fixed in all regions and the investment that occurs does not come on line in the simulation period. Thus, the behaviour of investment can only influence output through changes in the composition of final demand. 


\subsection{GTAP with international capital mobility}

The second model with which the UR experiment is conducted is GTAP with international capital mobility (GTAPICM). The ICM extension to GTAP is taken from GTAP's predecessor, the SALTER model (see Jomini et al. 1994; McDougall 1993). ${ }^{13}$ The extensions to the theoretical structure of GTAP describe wealth accumulation, and the international allocation of capital and investment. They also spell out government and private household sector accounts that include international asset ownership and international income payments.

GTAP, like SALTER, is a comparative-static model. In introducing wealth accumulation, time cannot be ignored completely in the model. That is, it is assumed that all shocks applied to the model represent discrete changes at a certain initial point in time, while the initial data and endogenous variables represent values observed at a certain final point in time. The simulation period is the interval between the initial and final points. This differs from a more complete, but not perfect, treatment of time where simulations are projections through time and agents are assumed to have adaptive expectations. This is the treatment of time in many recursivelydynamic CGE models, e.g., the MONASH model (Dixon and Rimmer 1997).

\subsubsection{Modifications to the GTAP theoretical structure}

The ICM extension requires the addition of two sets of assets: bonds and equity in productive assets (land, capital and natural resources) in each region. Bonds can be owned or owed by each region's representative private household and government. Equity in each region’s productive assets is owned entirely by the representative household. The extension also includes

\footnotetext{
13 This section contains only a brief description of the ICM extension. Those seeking further detail on the nature of the ICM extension should consult McDougall (1993) and Hanslow et al. (1999), upon which this section is based. Hanslow et al. (1999) documents all the modifications required to the theory (Chapter 3) and data (Appendix E) of GTAP to implement the ICM extension.
} 
income taxes on households. Income taxes are separated into taxes on labour and taxes on property income (land, capital, natural resources and net interest income from abroad).

The international allocation of capital is determined by international interest parity. Private households are assumed to maximise the rate of return (on all assets) and this imposes parity between the interest rate on bonds $\left(R B_{r}\right)$, the rate of return on equity in productive assets $\left(R E_{r}\right)$ and the rate of return on capital in each region $\left(R K_{r}\right)$ :

$$
\begin{gathered}
R B_{r}=R B, \\
R E_{r}=R B_{r}, \\
R K_{r}=R E_{r}, \\
R K_{j r}=R K_{r},
\end{gathered}
$$

where $R B$ is the global interest rate on bonds and $R K_{j r}$ is the rate of return on capital in industry $j$ in region $r$.

The total value of world stocks of capital, land and natural resources is equal to total net wealth of households and governments in all regions. There are three assumptions underlying this. First, household net wealth consists of equity in productive assets $\left(E_{r}\right)$ and net ownership of bonds $\left(B H_{r}\right)$; government net wealth consists of government net ownership of bonds $\left(B G_{r}\right)$. Second, the value of equity in productive assets is equal to the value of the underlying productive assets,

$$
E_{r}=V K_{r}+V N_{r}+V R_{r}
$$

where $V K_{r}, V N_{r}$ and $V R_{r}$ are the asset values of capital, land and natural resources in region $r$. Third, world net ownership of bonds $(B)$ is zero:

$$
B=\sum_{r} B H_{r}+B G_{r}=0
$$


Private household and government wealth is modelled as the outcome of a wealth accumulation process. Private households and governments are assumed to save some predetermined share of their net disposable income (households) or tax and interest receipts net of subsidies (government). It is also assumed that (i) real income grows at a constant rate through the simulation period, (ii) any change in the saving ratio is concentrated at the beginning of the simulation period, and (iii) changes in relative prices are concentrated at the beginning of the simulation period. The model takes the policy-induced deviations in income and saving in the final period, uses the above assumptions to deduce the deviation in the entire path of saving between the initial and final periods, and then translates this into a deviation in the final wealth that would have been accumulated by the interim savings. Deviation in the final world capital stock is then determined by the deviation in final world wealth. The allocation of capital across regions is discussed below.

The international allocation of investment is based on the same parity conditions as the international allocation of capital. To maintain these parity conditions, investment must be allocated across regions and industries so as to equalise time rates of change in rates of return. ${ }^{14}$ Since the underlying model is comparative-static in nature, it rules out the imposition of modelconsistent expectations, where rates of return expected to be earned in later periods are consistent with actual rates in those periods. Hence, in modelling expected rates of return, all that can be achieved is broad consistency with the behaviour of actual rates of return in the model.

Equalising time rates of change in rates of return requires three parity conditions that parallel equations (6)-(8) except that they are written in terms of the expected rate of change in the rate of return on bonds, equity and capital. The expected rate of change in the rate of return on capital $\left(E R K_{r}\right)$ is key here and is defined assuming: (i) $E R K_{r}$ at any given point in time

\footnotetext{
14 This new investment allocation mechanism replaces the GTAP investment allocation mechanism (equation (3)).
} 
depends only on the size of the capital stock; (ii) because the world economy grows over time, investors expect that capital stocks can also grow over time at some positive rate without a decline in $R K_{r}$; (iii) the elasticity of $E R K_{r}$ with respect to the expected size of the capital stock is fixed; and (iv) the rate of growth in the capital stock consistent with an expectation of no change over time in $R K_{r}$ is fixed.

The movement of capital between regions is facilitated by changes in regional bond holdings (debt). The benefit (cost) to a region buying (selling) bonds is the interest receipts (payments). Interest receipts (payments) now represent an additional source of real income and regional welfare. Thus, the GTAP definition of national income $\left(Y_{r}\right)$ is modified to include net income from abroad $\left(Y B_{r}\right)$, as well as domestic factor income $\left(Y K_{r}+Y L_{r}+Y N_{r}+Y R_{r}\right)$ (comprising capital, labour, land and natural resource income) and net indirect taxes $\left(T I_{r}\right)$ :

$$
Y_{r}=Y K_{r}+Y L_{r}+Y N_{r}+Y R_{r}+Y B_{r}+T I_{r}
$$

Net income from abroad is just interest income on bonds, defined as the product of the bond rate and the net ownership of bonds:

$$
Y B_{r}=R B_{r} B_{r} .
$$

\subsubsection{Modifications to the GTAP base data}

A variety of additional data are required for the extended model. These include private household and government net interest income, and income taxes on labour income and property income. An element measuring the world real bond rate is added, which allows asset values to be calculated from property income flows. This is set equal to the world rate of return on capital implied in the GTAP 4 database (McDougall et al. 1998), which is the base data used here. The real rate of return on equity for each region is also set equal to the world rate of return on capital 
implied in GTAP 4. Rates of growth in real private household income and real government receipts for each region (needed to calibrate the wealth accumulation dynamics) are set equal to the average rates of growth in real gross domestic product (GDP) over the period 1985-1995 for consistency with the base year (1995) in the GTAP 4 data. The length of the simulation period is set at 10 years. This is also used to calibrate the wealth accumulation dynamics.

Some changes to the existing GTAP 4 data were required to ensure consistency with the theory added in the ICM extension. The ICM extension models the accumulation of capital and wealth between two long-run equilibrium points. To prevent deviations from long-run equilibrium from distorting investment results, the capital stock was calibrated for long-run equilibrium. That is, it is adjusted so that the implied net (of depreciation) rates of return across regions are set equal to the world rate of return. This is done by amending the value of $K B_{r} \cdot{ }^{15}$ Net (of depreciation) saving was also adjusted to be positive for the Philippines and Hong Kong, which showed negative values in the base data. This was done by decreasing each region's value of depreciation. ${ }^{16}$

\subsubsection{Model closure}

The closure adopted for the simulations with GTAPICM is one that captures the long-run effects of liberalisation, typically a 10-year period. As such, this usually involves holding the level of employment and technology fixed. In contrast, the real wage and the capital stock are allowed to vary. On the demand side, private household consumption expenditure, government consumption expenditure and total net saving are set equal to fixed nominal shares of net national

\footnotetext{
15 This is a relatively simple method of calibrating the capital stock for long-run equilibrium. A more complex method is that used in Walmsley (1999), where shocks to output are applied to the model so as to achieve equalisation of regional rates of return on capital.

${ }^{16}$ With negative net saving, the allocation of income between consumption and savings can no longer be regarded as the result of a utility maximising decision. Left unchanged, this would present problems for the utility maximising theory in the model.
} 
product (as in standard GTAP). Income tax rates are determined by holding the government saving ratio (defined as the ratio of government savings to total government revenue) fixed. The trade balance is endogenous. The extended model allows the user to choose whether growth in the capital stock can be financed from both domestic and overseas saving (perfect capital mobility), or whether it must be fully financed from domestic saving (imperfect capital mobility). This choice governs the allocation of capital between regions. Both closures are implemented here.

\subsubsection{Regional and sectoral detail}

A 19-region aggregation is used for the simulations. The regions are Australia, New Zealand, Japan, South Korea, Indonesia, Malaysia, the Philippines, Singapore, Thailand, China, Hong Kong, Taiwan, Canada, the United States (US), Mexico, Chile, the rest of the Cairns Group (ROC), the European Union (EU) and the rest of the world (ROW). Except for the last three regions, all are stand alone regions in GTAP 4. ROC, EU and ROW are aggregations of existing GTAP 4 regions. ROC includes Colombia, Argentina, Brazil and Uruguay. EU includes the 15 EU members in 1995. All remaining regions are included in ROW.

The commodity aggregation is the complete 50-commodity grouping in GTAP 4 . The grouping represents agricultural, mining and manufactured goods to a relatively fine level. Only services are highly aggregated. Nevertheless, this is unimportant for the purposes of this experiment as the UR was expected to lead to little or no liberalisation in services (Hoekman 1995). 


\section{Implementing the Uruguay Round}

The starting data for the simulations is GTAP 4. This provides a snapshot of bilateral trade and protection for 1995. As such, it reflects partial UR implementation. ${ }^{17}$ Simulating the remaining implementation of the UR requires reducing protection to post-UR levels. The UR involved reducing protection provided by four instruments: import tariffs, export subsidies, output subsidies and the Multifibre Agreement (MFA). Calculating the changes required to simulate the remaining implementation of the UR differed for each instrument.

\subsection{Import tariffs}

The GTAP 3 database contains information on post-UR rates for import tariffs (McDougall 1997). These rates were compared with the rates in GTAP 4. Where import tariffs were (i) present in both databases and (ii) lower in GTAP 3 than GTAP 4, then the shock imposed was equal to the percentage difference between the two rates. Table 1 lists the percentage changes to the average ad valorem tariff rates for four major commodity groups in each region. Table 1 indicates that the highest average reductions were for agricultural, food processing and manufacturing commodities.

\footnotetext{
17 The UR was concluded in 1994 and allowed for yearly staged reductions in tariffs, with most final offer rates due to come into effect by January 1, 1999 (McDougall 1997).
} 
Table 1 Average reduction in ad valorem tariff rates by region, weighted by the ex-duty value of imports (percentage change)

\begin{tabular}{lrrrr}
\hline \hline Region & Agriculture & Mining & Food processing & Manufacturing \\
\hline Australia & -7.4 & -0.5 & -3.7 & -6.9 \\
New Zealand & -0.3 & -0.1 & -1.6 & -0.6 \\
Japan & -12.8 & -0.6 & -2.5 & -2.9 \\
South Korea & -8.9 & 0.0 & -2.6 & -2.5 \\
Indonesia & 0.0 & -1.2 & -0.5 & -2.9 \\
Malaysia & -9.0 & -2.8 & -6.0 & -8.3 \\
Philippines & -12.4 & -0.2 & -4.3 & -7.3 \\
Singapore & -20.3 & 0.0 & -11.6 & -0.7 \\
Thailand & -7.5 & -0.1 & -8.5 & -0.4 \\
China & -0.3 & -0.9 & -0.7 & -0.9 \\
Hong Kong & 0.0 & 0.0 & 0.0 & 0.0 \\
Taiwan & -0.1 & -0.8 & -1.9 & -8.0 \\
Canada & -1.5 & -0.1 & -4.6 & -2.5 \\
United States & -1.0 & -0.3 & -5.8 & -7.0 \\
Mexico & -3.4 & -0.5 & -0.2 & -0.5 \\
Chile & 0.0 & 0.0 & 0.0 & 0.0 \\
Rest of Cairns Group & -0.3 & -4.7 & -1.1 & -0.5 \\
European Union & -0.8 & -0.1 & -1.4 & -2.5 \\
Rest of World & -4.3 & -0.4 & -3.1 & -1.3 \\
\hline \hline
\end{tabular}

Source: Authors' calculations.

\subsection{Export subsidies}

Ingco (1995) estimated the reductions in export subsidies for agriculture and food processing in GTAP 3 needed to achieve the post-UR rates. These were $34 \%$ in industrial economies and 24\% in developing economies. ${ }^{18}$ Where export subsidies were present in GTAP 3 , these were reduced by $34 \%$ and $24 \%$ in industrial and developing economies. Where export subsidies were present in GTAP 4 and were higher than the adjusted GTAP 3 rates, the reductions applied were the percentage difference between the adjusted GTAP 3 and GTAP 4 export subsidies. Table 2 lists the reductions to the average ad valorem export subsidies in each region for agricultural and food processing commodities.

\footnotetext{
18 As per the UR agreement, Australia, New Zealand, Japan, Canada, the US and the EU are treated here as industrial economies; all other regions are treated as developing (GATT Secretariat 1994).
} 
Table 2 Average reduction in ad valorem export subsidy rates by region, weighted by the value of exports at domestic (pre-subsidy) prices (percentage change)

\begin{tabular}{lrr}
\hline \hline Region & Agriculture & Food processing \\
\hline Australia & -9.2 & -3.8 \\
New Zealand & 0.0 & 0.0 \\
Japan & -0.4 & 0.0 \\
South Korea & 0.0 & -0.3 \\
Indonesia & -0.1 & 0.0 \\
Malaysia & 0.0 & 0.0 \\
Philippines & -0.3 & -0.7 \\
Singapore & -8.7 & 0.0 \\
Thailand & 0.0 & -0.2 \\
China & -0.2 & -0.7 \\
Hong Kong & 0.0 & 0.0 \\
Taiwan & 0.0 & 0.0 \\
Canada & -4.5 & -1.7 \\
United States & 0.0 & -2.7 \\
Mexico & 0.0 & 0.0 \\
Chile & -0.3 & 0.0 \\
Rest of Cairns Group & -0.1 & -6.6 \\
European Union & -0.2 & -2.9 \\
Rest of World & 0.0 & -3.9 \\
\hline \hline
\end{tabular}

Source: Authors' calculations.

\subsection{Output subsidies}

Francois et al. (1995) estimated the reductions in output subsidies for agriculture and food processing in GTAP 3 needed to achieve post-UR rates. These were $20 \%$ in industrial economies and $13 \%$ in developing economies. Applying these reductions to the initial ad valorem output subsidy rates in GTAP 3, where they were present, gives the target post-UR rates applied here. Where output subsidies were also present in GTAP 4 and these were higher than the target postUR rates, then the reductions were calculated as the percentage difference between the two output subsidy rates. Table 3 summarises the reductions to average ad valorem output subsidies in each region for these commodities. 
Table 3 Average reduction in ad valorem output subsidies by region, weighted by the value of output at producers' (pre-subsidy) prices (percentage change)

\begin{tabular}{lrr}
\hline \hline Region & Agriculture & Food processing \\
\hline Australia & -14.7 & -14.5 \\
New Zealand & -5.8 & 0.0 \\
Japan & -9.8 & 0.0 \\
South Korea & 0.0 & 0.0 \\
Indonesia & 0.0 & 0.0 \\
Malaysia & 0.0 & 0.0 \\
Philippines & 0.0 & 0.0 \\
Singapore & 0.0 & 0.0 \\
Thailand & 0.0 & 0.0 \\
China & 0.0 & 0.0 \\
Hong Kong & 0.0 & 0.0 \\
Taiwan & 0.0 & 0.0 \\
Canada & -16.8 & 0.0 \\
United States & -8.2 & 0.0 \\
Mexico & -6.3 & -4.7 \\
Chile & 0.0 & -1.9 \\
Rest of Cairns Group & -1.9 & 0.0 \\
European Union & -7.5 & 0.0 \\
Rest of World & -10.2 & -4.8 \\
\hline \hline
\end{tabular}

Source: Authors' calculations.

\subsection{The Multifibre Agreement}

GTAP 4 contains estimated export tax equivalents of the quota restrictions existing under the MFA. These were reduced to zero in accordance with the UR, where it was agreed to completely abolish the MFA. Table 4 summarises the bilateral average export tax rates in GTAP 4 for textiles and wearing apparel. 
Table 4 Average bilateral MFA ad valorem export tax rates in GTAP 4, weighted by the value of exports at f.o.b. prices (percentage change)

\begin{tabular}{|c|c|c|c|c|}
\hline \multirow{2}{*}{ Exporting regions } & \multicolumn{4}{|c|}{ Importing regions } \\
\hline & Canada & United States & European Union & Rest of World \\
\hline South Korea & 2.0 & 2.0 & 1.2 & 0.0 \\
\hline Indonesia & 2.3 & 2.7 & 0.9 & 0.0 \\
\hline Malaysia & 3.7 & 3.7 & 1.4 & 0.1 \\
\hline Philippines & 2.6 & 2.6 & 0.9 & 0.1 \\
\hline Singapore & 0.6 & 0.6 & 0.2 & 0.0 \\
\hline Thailand & 5.5 & 6.7 & 2.1 & 0.1 \\
\hline China & 19.7 & 20.3 & 8.0 & 0.9 \\
\hline Hong Kong & 14.8 & 15.1 & 5.4 & 1.6 \\
\hline Taiwan & 2.4 & 2.5 & 1.2 & 0.0 \\
\hline Mexico & 0.1 & 0.0 & 0.1 & 0.0 \\
\hline Rest of Cairns Group & 0.0 & 0.1 & 0.0 & 0.0 \\
\hline Rest of World & 6.9 & 3.9 & 1.0 & 0.2 \\
\hline
\end{tabular}

Source: GTAP 4 database.

\section{Results}

Here we implement the UR as represented by the changes in import tariffs, export subsidies, output subsidies and export tax equivalents of the quota restrictions existing under the MFA (presented in Tables 1-4), using four different scenarios. The focus of our discussion is on the macroeconomic effects of the policy change rather than the microeconomic effects, as we are interested in testing the significance of the absence of a true long-run closure in GTAP and the long-run effects of capital reallocation between regions and capital accumulation within regions. So although the large-scale structural policy implemented here will lead to large industry effects, it is not informative, per se, to the main focus of the paper. Also note, the results presented here are illustrative and are not intended to provide specific guidance on the winners and losers of the UR implementation.

\subsection{Scenario 1: GTAP}

In this scenario, the investment allocation mechanism operates so as to equalise expected rates of return across regions $\left(r e_{r}\right)$ but there is no change in physical capital stocks $\left(k b_{r}\right)$ within 
the simulation period. With no change in endowments, changes in net output (real GDP) purely reflect changes in allocative efficiency. This can be shown using a formal definition of real GDP. We can define the percentage change in real GDP $\left(q_{r}\right)$ from the income side as a function of the change in the use of resources in the economy and/or the change in the efficiency with which resources are used in the economy, i.e.,

$$
q_{r}=S V A_{r} q v a_{r}+S T I_{r} q t i_{r}
$$

where $q v a_{r}$ and $q t i_{r}$ are the percentage changes in real value added and the quantity base upon which net (of subsidies) indirect taxes are levied, and $S V A_{r}$ and $S T I_{r}$ are the shares of value added and net indirect taxes in GDP.

$q v a_{r}$ measures the change in the use of resources. $q t i_{r}$ measures the change in the efficiency with which resources are used in the economy, i.e., allocative efficiency. This can happen via a change in tax rates (e.g., tariffs) and/or a change in the tax bases. Tax bases can change via price or quantity movements. GTAP distinguishes many indirect taxes (see Hertel and Tsigas 1997). Where the composition of sectoral outputs and sales do not change, $q v a_{r}$ and $q t i_{r}$ in (9) will move together, as $q t i_{r}$ is the weighted sum of sales and $q v a_{r}$ is the weighted sum of (net) industry outputs. But the changes in tariffs (and other distortions) will induce a change in each economy's production and sales structure; if the changes favour industries that are relatively highly taxed, $q t i_{r}$ will be positive, if the changes favour industries that are relatively lightly taxed (or subsidised), $q t i_{r}$ will be negative.

The changes in tax rates that comprise the implementation of the UR will necessarily lead to changes in $q t i_{r}$; with all primary factors fixed in GTAP, $q v a_{r}$ will equal zero. Thus, any changes in $q_{r}$ will be purely due to changes in allocative efficiency. Table 5 reports both $q t i_{r}$ and $q_{r}$. We see that most of the effects on $q_{r}$ are in the order of 0.1 and 0.6 with a simple 
average of 0.26; China (1.08\%) and Thailand (-0.01\%) are outliers. ${ }^{19}$ The effects on allocative efficiency vary widely relative to real GDP as indicated by the huge difference in the standard deviations: $21.89 \%$ versus $0.25 \%$. This reflects the degree of structural change in sales and industry outputs across regions due to the changes in tax rates. In general, developing countries and regions experience larger changes in allocative efficiency than developed countries and regions, reflecting a greater reliance on trade taxes for government revenue by developing countries and regions relative to developed countries and regions.

From the definition of $r e_{r}$ in equation (4), we can see that if $r e_{r}$ is equalised across regions then relative investment flows across regions $\left(q i_{r}\right)$ will mainly reflect relative current rates of return across regions $\left(r c_{r}\right)$ as investment will seek out regions with the highest relative returns on capital. The correlation between $q i_{r}$ and $r c_{r}$ is shown in Table 5; regions where $r c_{r}$ is relatively high (Australia: 8.6\%; Singapore: 5.1\%; Philippines: 4.7\%) experience the largest increases in real investment (Australia: 10.9\%; Singapore: 4.8\%; Philippines: 4.7\%); regions where $r c_{r}$ is relatively low (Mexico: $-0.5 \%$; European Union: $-0.1 \%$; Japan: $-0.1 \%$ ) experience falls in $q i_{r}$ (Mexico: $-3.1 \%$; European Union: $-0.4 \%$; Japan: $\left.-0.3 \%\right)^{20}$

\footnotetext{
19 Thailand experiences a negative change in allocative efficiency as the biggest increases in domestic output are in the most highly protected industries in the base data, e.g., wheat, sugar cane and sugar beet, dairy products, sugar, and beverages and tobacco products.

20 This assumes that $\left(\frac{K E_{r}}{K B_{r}}\right) \approx 1$ for all regions. This is a good approximation of the results in this scenario, as the capital accumulation relationship (equation (5)) makes $K E_{r}$ mainly a function of $K B_{r}$ (which is fixed) because investment-capital ratios are around 0.1 or less for all regions.
} 
Table 5 The effects of UR implementation using GTAP (percentage change)

\begin{tabular}{|c|c|c|c|c|c|}
\hline Region & $\begin{array}{l}\text { Expected rate } \\
\text { of return }\left(r e_{r}\right)\end{array}$ & $\frac{\text { Current rate of }}{\text { return }\left(r c_{r}\right)}$ & $\begin{array}{r}\underline{\text { Real }} \\
\text { investment }\end{array}$ & $\begin{array}{r}\text { Allocative } \\
\text { efficiency }\left(q t i_{r}\right)\end{array}$ & $\frac{\text { Real GDP }}{\left(q_{r}\right)}$ \\
\hline Australia & 0.23 & 8.62 & 10.91 & 8.07 & 0.56 \\
\hline New Zealand & 0.23 & 2.35 & 3.76 & 1.06 & 0.14 \\
\hline Japan & 0.23 & -0.06 & -0.30 & 1.05 & 0.08 \\
\hline South Korea & 0.23 & 0.76 & 0.55 & 1.58 & 0.20 \\
\hline Indonesia & 0.23 & 1.99 & 2.97 & 36.84 & 0.28 \\
\hline Malaysia & 0.23 & 3.96 & 4.34 & 1.33 & 0.34 \\
\hline Philippines & 0.23 & 4.72 & 7.04 & 3.57 & 0.58 \\
\hline Singapore & 0.23 & 5.06 & 4.80 & 3.43 & 0.38 \\
\hline Thailand & 0.23 & 0.40 & 0.26 & -0.12 & -0.01 \\
\hline China & 0.23 & 2.26 & 2.16 & 4.92 & 1.08 \\
\hline Hong Kong & 0.23 & 1.39 & 1.43 & 95.28 & 0.40 \\
\hline Taiwan & 0.23 & 1.63 & 2.11 & 1.47 & 0.14 \\
\hline Canada & 0.23 & 0.01 & -0.39 & 0.63 & 0.07 \\
\hline United States & 0.23 & 0.08 & -0.27 & 2.03 & 0.15 \\
\hline Mexico & 0.23 & -0.51 & -3.13 & 0.28 & 0.03 \\
\hline Chile & 0.23 & 1.04 & 1.78 & 0.52 & 0.07 \\
\hline Rest of Cairns Group & 0.23 & 0.49 & 0.61 & 0.77 & 0.07 \\
\hline European Union & 0.23 & -0.10 & -0.40 & 3.07 & 0.21 \\
\hline Rest of World & 0.23 & 0.38 & 0.23 & 1.35 & 0.15 \\
\hline Mean & & 1.81 & 2.02 & 8.80 & 0.26 \\
\hline Standard deviation & & 2.26 & 3.09 & 21.89 & 0.25 \\
\hline
\end{tabular}

Source: Model simulation.

As all primary factors are fixed, changes in $r c_{r}$ (as well as other factor returns) purely reflect changes in the demand for capital. A positive $r c_{r}$ reflects an excess demand for capital at the initial $r c_{r}$; a negative $r c_{r}$ reflects an excess supply of capital at the initial $r c_{r}$. Whether the demand for capital increases or decreases, and the extent of the increase or decrease, will depend on the net effect upon primary factor demands of the four tax instruments being lowered with UR implementation. Each tax instrument will have countervailing effects upon primary factor demands in a given region. For example, lower multilateral import tariffs affect the imports of a given region differently from its exports, which in turn affect the demand for capital differently.

1. Lower import tariffs reduce the price of imported products; domestic industries and consumers substitute imported for domestic products and, ceteris paribus, domestic importcompeting industries contract. Demands for primary factors fall; this reduces returns for all primary factors (including capital returns) as they are fixed in supply. 
2. The increased demand for imported products favours regions from which imported products are sourced. Increased demand for these exports causes domestic industries in exporting regions to expand. Ceteris paribus, expanding domestic industries increases the overall demand for primary factors. This benefits all primary factors by raising factor returns.

Clearly, if effect 1 dominates effect 2 for a given region, then the demand for primary factors will fall and $r c_{r}$ will also fall; if effect 2 dominates effect 1 , then the demand for primary factors will rise and $r c_{r}$ will also rise. As reductions in export and output subsidies, and export taxes related to the MFA will operate via similar mechanisms to those described above for changes in import tariffs, we do not explain these here and take them as understood by the reader.

Thus, those regions that experience the largest increases in $r c_{r}$ are those whose demand expands by the most due to the UR implementation (Australia, Singapore, Philippines); those regions that experience the smallest increases or decreases in $r c_{r}$ are those whose demand expands by the least or falls due to the UR implementation (Mexico, European Union, Japan). Hence, the allocation of investment across regions reflects the effects of the UR implementation on regional factor demands.

\subsection{Scenario 2: GTAP with endogenous regional capital stocks}

Above we presented results for how a large-scale structural policy, like the UR, is usually implemented in GTAP. The limitations of the results are obvious: regional capital stocks $\left(k b_{r}\right)$ are held fixed despite the fact that physical capital investment responds endogenously to the policy. The shortcoming is sometimes addressed by imposing equalisation of $r c_{r}$ across regions and allowing $k b_{r}$ to vary, e.g., see Adams (2005). We implement such a treatment in this section. 
With endogenous $k b_{r}, q v a_{r}$ will make a non-zero contribution to $q_{r}$, as

$$
q v a_{r}=S K_{r} k b_{r}+S L_{r} q l_{r}+S N_{r} q n_{r}+S R_{r} q r_{r}
$$

where $q l_{r}, q n_{r}$ and $q r_{r}$ are the percentage changes in labour, land and natural resources, and the $S$ s are the relevant shares of GDP. So although $q l_{r}, q n_{r}$ and $q r_{r}$ will equal zero, $k b_{r}$ will be non-zero. Thus, the change in $q_{r}$ will be explained by changes in the use of $k b_{r}$ and the change in allocative efficiency $\left(q t i_{r}\right)$. Table 6 reports the results.

Table 6 The effects of UR implementation using GTAP with endogenous regional capital stocks (percentage change)

\begin{tabular}{|c|c|c|c|c|c|c|}
\hline Region & $\frac{\text { Expected }}{\underline{\text { rate of }}}$ & $\frac{\text { Current rate }}{\frac{\text { of return }}{\left(r c_{r}\right)}}$ & $\begin{array}{r}\underline{\text { Real }} \\
\underline{\text { investment }}\end{array}$ & $\begin{array}{r}\text { Capital } \\
\underline{\text { stock }}\left(k b_{r}\right)\end{array}$ & $\frac{\frac{\text { Allocative }}{\text { efficiency }}}{\left(q t i_{r}\right)}$ & $\frac{\text { Real GDP }}{\left(q_{r}\right)}$ \\
\hline Australia & 0.72 & 1.00 & 6.52 & 6.12 & 8.31 & 2.72 \\
\hline New Zealand & 0.72 & 1.00 & 1.93 & 1.42 & 1.18 & 0.69 \\
\hline Japan & 0.72 & 1.00 & -0.94 & -1.23 & 0.56 & -0.43 \\
\hline South Korea & 0.72 & 1.00 & -0.07 & -0.36 & 1.39 & 0.03 \\
\hline Indonesia & 0.72 & 1.00 & 1.60 & 1.18 & 35.57 & 0.83 \\
\hline Malaysia & 0.72 & 1.00 & 4.04 & 3.70 & 3.72 & 2.49 \\
\hline Philippines & 0.72 & 1.00 & 4.51 & 4.04 & 5.11 & 2.50 \\
\hline Singapore & 0.72 & 1.00 & 4.76 & 4.46 & 5.03 & 2.65 \\
\hline Thailand & 0.72 & 1.00 & -1.18 & -1.57 & -1.46 & -1.10 \\
\hline China & 0.72 & 1.00 & 1.79 & 1.49 & 5.38 & 1.73 \\
\hline Hong Kong & 0.72 & 1.00 & 1.14 & 0.70 & 95.26 & 0.82 \\
\hline Taiwan & 0.72 & 1.00 & 1.10 & 0.69 & 1.58 & 0.36 \\
\hline Canada & 0.72 & 1.00 & -0.54 & -1.06 & 0.23 & -0.35 \\
\hline United States & 0.72 & 1.00 & -0.63 & -1.12 & 1.67 & -0.25 \\
\hline Mexico & 0.72 & 1.00 & -1.53 & -2.69 & -1.92 & -1.73 \\
\hline Chile & 0.72 & 1.00 & 0.29 & -0.32 & 0.11 & -0.15 \\
\hline Rest of Cairns Group & 0.72 & 1.00 & -0.23 & -0.89 & 0.24 & -0.39 \\
\hline European Union & 0.72 & 1.00 & -0.75 & -1.08 & 2.77 & -0.14 \\
\hline Rest of World & 0.72 & 1.00 & -0.28 & -0.68 & 1.09 & -0.13 \\
\hline Mean & & & 1.13 & 0.67 & 8.73 & 0.53 \\
\hline Standard deviation & & & 2.24 & 2.31 & 21.86 & 1.28 \\
\hline
\end{tabular}

Source: Model simulation.

Allowing regional capital stocks to respond to the UR implementation leads to real GDP effects that are twice as large compared to when capital stocks are fixed, as reflected in the mean of $0.53 \%$ here versus $0.26 \%$ in scenario 1 . There is also five times as much variability in real 
GDP effects, as reflected in the standard deviation of $1.28 \%$ here versus $0.25 \%$ in scenario 1 . Results for individual regions confirm these observations: regions that experienced the largest increases in GDP in scenario 1 now experience even larger increases (China: 1.7\% cf. 1.1\%; Philippines: $2.5 \%$ cf. $0.6 \%$; Australia: $2.7 \%$ cf. $0.6 \%$ ); regions that experienced the smallest increases (or decreases) in GDP in scenario 1 now experience decreases (or larger decreases) (Thailand: $-1.1 \%$ cf. $-0.01 \%$; Mexico: $-1.7 \%$ cf. $0 \%$; Canada: $-0.4 \%$ cf. $0.1 \%$ ).

The differences in real GDP between scenarios 1 and 2 are mostly due to the endogenous response of capital stocks, as the allocative efficiency effects are very similar in both scenarios as reflected in the similarity of the mean and standard deviation. The changes in capital stocks are larger than the real GDP effects (mean of $0.67 \%$ cf. $0.58 \%$ ) and much more variable (standard deviation of $2.31 \%$ cf. $1.28 \%$ ). About half of all regions experience a fall in their capital stock, which, in turn, reduces real GDP in most of these regions. A major limitation of assuming regional capital stocks are fixed when evaluating a large-scale structural policy is identified by the large differences between capital and real GDP responses here versus scenario 1.

The movements in regional capital stocks reflect investment responses. Regions where investment increases strongly also experience a strong capital stock response, and vice versa. The relative investment responses across regions in scenario 2 are largely in line with those observed in scenario 1: they are strongest in Australia, Singapore and the Philippines; they are weakest in Mexico, the EU and Japan. Nevertheless, overall the investment responses are smaller than before (mean of $1.1 \%$ cf. $2 \%$ ) and less variable (standard deviation of $2.2 \%$ cf. $3.1 \%$ ).

Smaller and less variable investment responses are consistent with the investment allocation mechanism in GTAP, i.e., equalisation of $r e_{r}$ across regions. If we take a linearised version of the definition of $r e_{r}$ in equation (4),

$$
r e_{r}=r c_{r}-\rho\left[k e_{r}-k b_{r}\right]
$$


we see that (i) if $r c_{r}$ is equalised across regions, which it is in this scenario, and (ii) if beginningof-period capital stocks $\left(k b_{r}\right)$ are endogenous and therefore diverge from end-of-period capital stocks $\left(k e_{r}\right)$ by less than before, then equalising $r e_{r}$ across regions requires smaller overall investment responses and less variable responses across regions. This is consistent with what is observed about investment responses here versus scenario 1.

\subsection{Scenario 3: GTAPICM with perfect capital mobility}

Above we allowed regional capital stocks to vary in GTAP so that the model is able to simulate the long-run effects of a large-scale structural policy; this addresses a major limitation of the model in evaluating such policies. Nevertheless, a remaining major limitation of this approach is the assumption that all initial capital stocks are domestically owned, and that any changes in regional capital stocks due to the policy continue to be owned by residents. Thus, above we observe that regions with significant foreign ownership of their capital stock that experience a significant expansion in their capital stock (such as Australia) are predicted to see a significant increase in their net output (real GDP) and (possibly) welfare. This result ignores the effect on Australian national income of expanding already significant foreign ownership of the capital stock and the concomitant increase in foreign interest payments. Therefore it is likely that the welfare effects will be much less favourable than is predicted by the results in scenario 2 .

A converse example is that of Japan, which has significant ownership of capital stocks in other countries. Scenario 2 predicts a fall in net output due to the UR implementation. This ignores the flows of foreign interest receipts from existing foreign assets and the increase in these flows due to increased investment abroad by Japan. Thus, in this case, it is likely that the welfare effects will be much less unfavourable than is predicted by the results in scenario 2 . 
These limitations can be addressed by applying GTAPICM; the model outlined in Section 2.2. GTAPICM differs from GTAP in two fundamental ways. One, private households and governments are able to accumulate wealth and, two, capital is free to move between regions. Wealth accumulation includes international asset ownership and international income payments. Consequently, accurate welfare calculations are possible even though capital moves between regions. Here we implement the UR using GTAPICM assuming that capital is perfectly mobile and can move to those regions where it can earn the highest return; Table 7 reports the results.

In this scenario, we observe real GDP effects for most regions that are quite different from scenario 2 . In scenario 2, nine regions are predicted to experience lower GDP whereas here only three regions are predicted to experience lower GDP. Furthermore, these three regions (Japan, Canada, Mexico) experience much smaller contractions than in scenario 2. The more favourable GDP effects here are reflected in a mean of $0.9 \%$ compared with $0.5 \%$ in scenario 2 . The differences are mainly due to more favourable capital stock responses (mean of $1.5 \%$ here compared with $0.7 \%$ earlier): regions experience either smaller contractions than before or small expansions compared with contractions before.

The differences in capital stock responses between scenarios 2 and 3 reflect differences in investment responses. In GTAPICM, investment is allocated across regions and industries so as to equalise time rates of change in rates of return across all asset classes, i.e., bonds, capital, land and natural resources. So compared with scenario 2, investment allocation across regions is more "rational”, in that investors consider information on all asset returns rather than just information on capital returns. 
Table 7 The effects of UR implementation using GTAPICM with perfect capital mobility (percentage change or change)

\begin{tabular}{|c|c|c|c|c|c|c|}
\hline$\underline{\text { Region }}$ & $\underline{\text { Real }}$ & $\frac{\text { Capital stock }}{\left(k b_{r}\right)}$ & $\begin{array}{r}\text { Allocative } \\
\text { efficiency }\left(q t i_{r}\right)\end{array}$ & $\frac{\text { Real GDP }}{\left(q_{r}\right)}$ & $\underline{\underline{\text { Net interest }}}$ & $\frac{\text { Real }}{\underline{\text { GNP }}}$ \\
\hline Australia & 5.80 & 5.75 & 7.01 & 2.50 & -0.0089 & 2.32 \\
\hline New Zealand & 2.04 & 1.96 & 0.90 & 0.86 & -0.0041 & 1.41 \\
\hline Japan & -0.32 & -0.36 & 0.93 & -0.06 & 0.0009 & 0.01 \\
\hline South Korea & 0.65 & 0.60 & 1.85 & 0.47 & -0.0017 & 0.29 \\
\hline Indonesia & 1.97 & 1.88 & 35.89 & 1.16 & -0.0068 & 0.21 \\
\hline Malaysia & 4.39 & 4.33 & 4.13 & 2.85 & -0.0155 & 0.40 \\
\hline Philippines & 3.60 & 3.53 & 5.00 & 2.28 & -0.0122 & -0.86 \\
\hline Singapore & 5.22 & 5.18 & 4.94 & 2.98 & -0.0149 & 2.26 \\
\hline Thailand & 0.33 & 0.21 & -0.07 & 0.12 & -0.0017 & 0.26 \\
\hline China & 2.37 & 2.32 & 5.81 & 2.13 & -0.0030 & 1.40 \\
\hline Hong Kong & 1.94 & 1.84 & 99.30 & 1.39 & -0.0090 & 0.18 \\
\hline Taiwan & 1.45 & 1.38 & 1.74 & 0.61 & -0.0030 & 0.23 \\
\hline Canada & -0.20 & -0.26 & 0.66 & -0.01 & 0.0009 & 0.18 \\
\hline United States & -0.21 & -0.26 & 2.22 & 0.08 & 0.0005 & 0.20 \\
\hline Mexico & -0.75 & -0.96 & -0.48 & -0.60 & 0.0049 & -0.22 \\
\hline Chile & 0.85 & 0.75 & 0.56 & 0.46 & -0.0010 & 0.77 \\
\hline Rest of Cairns Group & 0.19 & 0.08 & 0.55 & 0.09 & -0.0007 & 0.07 \\
\hline European Union & -0.30 & -0.33 & 3.12 & 0.11 & 0.0011 & 0.17 \\
\hline Rest of World & 0.08 & 0.03 & 1.40 & 0.16 & -0.0002 & 0.05 \\
\hline Mean & 1.53 & 1.46 & 9.23 & 0.93 & -0.0039 & 0.49 \\
\hline Standard deviation & 1.92 & 1.93 & 22.60 & 1.08 & 0.0056 & 0.79 \\
\hline
\end{tabular}

Source: Model simulation.

With international ownership of assets defined and tracked through any simulation, GTAPICM can accurately estimate welfare changes from the international mobility of capital. We see that for over half of the regions, welfare (real GNP) diverges markedly from net output (real GDP). The differences are purely due to international income flows between regions. Some debtor regions (Australia, South Korea, Indonesia, Malaysia, China, Rest of Cairns Group) show smaller welfare gains than net output gains due to increased international borrowing and interest payments; whereas some creditor regions (Japan, Canada) show welfare gains compared with net output contractions due to increased international lending and interest receipts. These differences between net output and welfare could not be observed without tracking international asset positions for each region. A major limitation of assuming all regional capital stocks are domestically owned and remain domestically owned when evaluating a large-scale structural policy is identified by the large differences between real GDP and real GNP responses. 


\subsection{Scenario 4: GTAPICM with imperfect capital mobility}

Scenario 3 assumes a high degree of international capital mobility so that regions are able to fund any growth in their capital stocks from both domestic and overseas saving. There is a large body of empirical literature, spawned by the work of Feldstein and Horioka (1980), that establishes that capital is imperfectly mobile internationally given the empirical regularity that domestic saving and investment move together. In view of this empirical regularity, it seems appropriate to implement the UR assuming that all growth in regional stocks be funded exclusively from domestic saving, and contrast the results to scenario 3. Forcing all growth in regional capital stocks to be funded exclusively from domestic saving is achieved by holding regional bond-to-income ratios fixed and allowing rates of return on productive assets to vary across regions.

Assuming that capital is imperfectly mobile internationally makes a significant difference to the real GDP estimates (Table 8) compared to a situation where capital is assumed to be perfectly mobile internationally (scenario 3). Almost every region that experiences a net output gain in scenario 3 now experiences either a smaller output gain or an output loss; the US and the EU are the only exceptions. This is reflected in the mean result being less than one-half of that observed in scenario 3 (0.4\% cf. $0.9 \%)$; variability is also much lower ( $0.4 \%$ cf. $1.1 \%)$. 
Table 8 The effects of UR implementation using GTAPICM with imperfect capital mobility (percentage change or change)

\begin{tabular}{|c|c|c|c|c|c|c|}
\hline$\underline{\text { Region }}$ & $\underline{\text { Real }}$ & $\frac{\text { Capital stock }}{\left(k b_{r}\right)}$ & $\begin{array}{r}\text { Allocative } \\
\text { efficiency }\left(q t i_{r}\right)\end{array}$ & $\frac{\text { Real GDP }}{\left(q_{r}\right)}$ & $\underline{\underline{\text { Net interest }}}$ & $\frac{\text { Real }}{\underline{\text { GNP }}}$ \\
\hline Australia & 1.95 & 1.88 & 6.33 & 1.11 & -0.0004 & 2.02 \\
\hline New Zealand & 0.75 & 0.64 & 0.69 & 0.34 & -0.0004 & 1.30 \\
\hline Japan & 0.05 & -0.01 & 1.05 & 0.08 & 0.0001 & 0.05 \\
\hline South Korea & 0.14 & 0.06 & 1.58 & 0.22 & -0.0001 & 0.23 \\
\hline Indonesia & 0.47 & 0.33 & 34.79 & 0.43 & -0.0004 & 0.25 \\
\hline Malaysia & 0.03 & -0.06 & 1.44 & 0.33 & -0.0004 & -0.02 \\
\hline Philippines & 0.09 & -0.01 & 2.82 & 0.46 & -0.0002 & -0.98 \\
\hline Singapore & 0.84 & 0.78 & 3.41 & 0.75 & 0.0001 & 2.45 \\
\hline Thailand & 0.10 & -0.09 & -0.25 & -0.08 & -0.0002 & 0.21 \\
\hline China & 1.45 & 1.38 & 5.28 & 1.67 & -0.0010 & 1.18 \\
\hline Hong Kong & 0.14 & -0.02 & 96.84 & 0.40 & 0.0001 & 0.35 \\
\hline Taiwan & 0.36 & 0.27 & 1.39 & 0.22 & 0.0001 & 0.18 \\
\hline Canada & 0.13 & 0.04 & 0.72 & 0.10 & 0.0000 & 0.19 \\
\hline United States & 0.03 & -0.05 & 2.21 & 0.15 & 0.0000 & 0.21 \\
\hline Mexico & 0.36 & 0.03 & 0.31 & 0.04 & -0.0003 & -0.19 \\
\hline Chile & 0.73 & 0.57 & 0.53 & 0.36 & -0.0005 & 0.75 \\
\hline Rest of Cairns Group & 0.07 & -0.09 & 0.52 & 0.00 & -0.0003 & 0.04 \\
\hline European Union & 0.30 & 0.25 & 3.23 & 0.30 & 0.0000 & 0.22 \\
\hline Rest of World & -0.44 & -0.52 & 1.22 & -0.06 & 0.0014 & 0.01 \\
\hline Mean & 0.40 & 0.28 & 8.64 & 0.36 & -0.0001 & 0.44 \\
\hline Standard deviation & 0.54 & 0.55 & 22.11 & 0.42 & 0.0005 & 0.78 \\
\hline
\end{tabular}

Source: Model simulation.

The differences in real GDP results are almost solely due to much smaller capital stock expansions for all regions. Without exception, every region that experiences a capital stock expansion in scenario 3 now experiences either a smaller capital stock expansion or a capital stock contraction. As all capital stock growth must be funded domestically, the differences in capital stock expansions between scenarios 3 and 4 represent the degree of foreign investment that occurs when capital is assumed to be perfectly mobile internationally. So regions whose saving does not respond strongly to the UR implementation (e.g., Korea and Malaysia) experience little change in their capital stocks when they are forced to use domestic saving to fund capital stock growth. Conversely, regions whose saving responds strongly to the policy change either (i) still experience noticeable expansions in their capital stocks (e.g., Australia, New Zealand, China, Chile), or (ii) experience much smaller contractions or expansions (e.g., Japan, Canada, US, Mexico, EU) when they are forced to use domestic savings to fund domestic 
rather foreign capital stock growth. Much lower real GDP variability is a function of much lower capital stock variability across regions (standard deviation of $0.6 \%$ versus $1.9 \%$ ).

An interesting feature of the welfare results between this scenario and scenario 3 is their similarity, both in terms of overall size (mean of $0.4 \%$ versus $0.5 \%$ ) and variability (standard deviation of $0.8 \%$ in both scenarios). A less formal comparison of welfare results supports this observation for most regions. The similarity in welfare results between this scenario and scenario 3 is to be contrasted with the large differences in real GDP results. These observations confirm that tracking cross-border ownership of capital captures the true welfare effects for a region even when large outward or inward foreign investment occurs, such as when perfect capital mobility is assumed. So the degree of international capital mobility assumed is not so important for estimating welfare effects so long as cross-border ownership of capital is tracked.

\section{Concluding remarks}

Baldwin (1992) and Willenbockel (1999) have together formally demonstrated the importance of modelling capital accumulation, reallocation and ownership when analysing the long-run effects of large-scale structural policies. Apart from some notable exceptions, such as Francois et al. (1995) and Walmsley (2002), the applied trade policy modelling literature has, for the most part, ignored the issue of capital accumulation, reallocation and ownership when analysing large-scale structural policies. We address this issue here by presenting an approach to modelling capital accumulation, mobility and ownership.

The approach is applied to the GTAP model, which is one of the most commonly used in quantifying the effects of large-scale structural policies but suffers from the limitation of ignoring the issue of capital accumulation, mobility and ownership. The theoretical and data structure of GTAP is extended to describe wealth and capital accumulation, and the international allocation of capital and investment. It is also extended to define government and private household sector 
accounts that include international asset ownership and international income payments. The extended model (GTAPICM) facilitates the international movement of capital in a way that allows the regional welfare indicators to fully reflect the benefits (higher capital stocks and output) and costs (higher debt and interest payments) of attracting capital to a given region.

The treatment of international capital mobility, accumulation and ownership outlined here allows for regional capital accumulation (as in Francois et al. (1995) and Walmsley (2002)) with cross-border capital ownership (as in Walmsley (2002) but absent in Francois et al. (1995)). Thus, although the approach allows changes in regional welfare to be accurately tracked, it does not require the high theoretical and data demands that come with tracking bilateral ownership of capital as in Walmsley (2002). This is one of the contributions of our paper: to provide policy analysts a middle approach to analysing the effects of large-scale structural policies that allows for capital mobility, accumulation, and ownership without heavy theoretical and data demands.

We test the limitations of using a model like GTAP for long-run analysis of large-scale structural policies by moving from an economic environment of fixed capital stocks and no crossborder ownership of capital (GTAP) to an economic environment that allows for wealth and capital accumulation, and cross-border ownership of capital (GTAPICM). We do this in four steps (scenarios) while applying the complete implementation of the Uruguay Round of trade negotiations (UR).

Our simulations confirm the applied-theoretic findings of Willenbockel (1999) using a tworegion, two-sector model. That is, the absence of wealth and capital accumulation, and crossborder ownership of capital in GTAP (and models like GTAP) ignores significant mechanisms that strongly affect net output and welfare. In the case of the UR, the original model and the extended model give broadly similar regional welfare effects for regions whose capital stocks do not respond strongly to the policy change, and do not have very large initial foreign borrowings combined with a low saving rate. Where initial foreign borrowings are very high and the saving 
rate is low, the two models give welfare effects of a different sign. For regions whose capital stocks do respond strongly to the policy change, the welfare effects are strongly underestimated by GTAP relative to the extended model, regardless of initial foreign borrowings and the saving rate. This is another contribution of our paper: to demonstrate to applied trade policy practitioners the relative merits and limitations of different treatments of international capital mobility, accumulation and ownership using a widely-used and widely-available trade policy model and a single, consistent experiment. 


\section{References}

Adams, P.D. (2005), 'Interpretation of results from CGE models such as GTAP', Journal of Policy Modeling, vol. 27, no. 8, pp. 941-59.

Anderson, K., Martin, W. and Valenzuela, E. (2006), 'The relative importance of global agricultural subsidies and market access’, World Trade Review, vol. 5, no. 3, pp. 357-76.

Anderson, K. and Pangestu, M. (1998), 'Structural changes in a reforming world economy: Implications for Indonesia', Bulletin of Indonesian Economic Studies, vol. 34, no. 3, pp. 85113.

Baldwin, R.E. (1992), 'Measurable dynamic gains from trade', Journal of Political Economy, vol. 100 , no. $1,162-174$.

Brockmeier, M. and Pelikan, J. (2008), 'Agricultural market access: A moving target in the WTO negotiations?’, Food Policy, vol. 33, no. 3, pp. 250-9.

Dixon, P.B., Parmenter, B.R., Powell, A.A. and Wilcoxen, P.J. (1992), Notes and Problems in Applied General Equilibrium Economics, North-Holland, Amsterdam.

Dixon, P.B. and Rimmer, M.T. (2002), Dynamic General Equilibrium Modelling for Forecasting and Policy: A Practical Guide and Documentation of MONASH, North-Holland, Amsterdam. (earlier version available at http://www.monash.edu.au/policy/monbook2.htm)

Elbehri, A., Hertel, T., Ingco, M. and Pearson, K.R. (2000), 'Partial liberalization of the world sugar market: a general equilibrium analysis of tariff-rate quota regimes', paper presented at $3^{\text {rd }}$ Annual Conference on Global Economic Analysis, Melbourne, 28-30 June (available at http://www.monash.edu.au/policy/cnprog1.htm).

Feldstein, M. and Horioka, C. (1980) 'Domestic savings and international capital flows', The Economic Journal, vol. 90, no. 357, pp. 314-29.

Fernandez de Cordoba, S., Laird, S. and Vanzetti, D. (2005), 'Trick or treat? Development challenges in the WTO negotiations on industrial tariffs', The World Economy, vol. 28, no. 10, pp. 1375-1400.

Francois, J.F., McDonald, B. and Nordstrom, H. (1995), 'Assessing the Uruguay Round', paper presented at the World Bank conference on The Uruguay Round and the Developing Economies, Washington DC, 26-27 January (revised March).

Fugazza, M. and Vanzetti, D. (2008), 'A South-South survival strategy: The potential for trade among developing countries', The World Economy, vol. 31, no. 5, pp. 663-84. 
GATT Secretariat (1994), 'The Results of the Uruguay Round of Multilateral Trade Negotiations - Market Access for Goods and Services: Overview of the Results', Geneva, http://www.wto.org/wto/legal/uround.htm (accessed 15 February 1999).

Hanslow, K., Phamduc, T., and Verikios, G. (1999), The Structure of the FTAP Model, Research Memorandum MC-58, Productivity Commission, Canberra (available at http://www.pc.gov.au/research/researchmemorandum/ftap).

Harrison, W.J. and Pearson, K.R. (1996), 'Computing solutions for large general equilibrium models using GEMPACK’, Computational Economics, vol. 9, no. 3, pp. 83-127.

Hertel, T.W. and Tsigas, M.E. (1997), 'Structure of GTAP', in Hertel, T.W. (ed.), Global Trade Analysis: Modeling and Applications, Cambridge University Press, Cambridge, UK, pp. 1373.

Hoekman, B. (1995), 'Liberalizing trade in services', in W. Martin and A. Winters (eds.), The Uruguay Round and the Developing Economies, World Bank Discussion Paper 201.

Ianchovichina, E. and McDougall, R. (2000), 'Theoretical Structure of Dynamic GTAP', GTAP Technical Paper No. 17, Center for Global Trade Analysis, Purdue University, West Lafayette (available at https://www.gtap.agecon.purdue.edu/resources/res_display.asp?RecordID=480).

Ingco, M.D. (1995), 'Agricultural liberalisation and the Uruguay Round: One step forward, one step back?', supplementary paper for the World Bank conference on The Uruguay Round and the Developing Economies, Washington DC, 26-27 January.

Islam, S. (2003), 'Expansions of the European Union and the NAFTA: Implications for new and non-member countries', Applied Econometrics and International Development, vol. 3, no. 2, pp. 55-72.

Johansen, L. (1960), A Multisectoral Study of Economic Growth, North-Holland, Amsterdam.

Jomini, P., McDougall, R., Watts, G. and Dee, P.S. (1994), The SALTER Model of the World Economy: Model Structure, Database and Parameters, Industry Commission, Canberra (available at http://www.pc.gov.au/ic/research/models/saltermodel/workingpaper24).

Krugman, P.R. and Obstfeld, M. (2003), International Economics: Theory and Policy, AddisonWesley, Boston.

McDougall, R. (1993), Incorporating International Capital Mobility into SALTER, SALTER Working Paper No. 21, Industry Commission, Canberra (available at http://www.pc.gov.au/ic/research/models/saltermodel/workingpaper21). 
McDougall, R.A. (ed.) (1997), Global Trade, Assistance, and Protection: The GTAP 3 Data Base, Center for Global Trade Analysis, Purdue University, West Lafayette. (available at https://www.gtap.agecon.purdue.edu/databases/v3/v3_doco.asp)

McDougall, R.A., Elbehri, A. and Truong, T.P. (1998), Global Trade, Assistance, and Protection: The GTAP 4 Data Base, Center for Global Trade Analysis, Purdue University, West Lafayette (available at https://www.gtap.agecon.purdue.edu/databases/v4/v4_doco.asp).

McKibbin, W.J. and Wilcoxen, P.J. (1999), 'The theoretical and empirical structure of the GCubed model', Economic Modelling, vol. 16, issue 1, pp. 123-48.

Nijkamp, P., Wang, S. and Kremers, H. (2005), 'Modeling the impacts of international climate change policies in a CGE context: The use of the GTAP-E model', Economic Modelling, vol. 22, issue 6, pp. 955-74.

Smith, M.A.M. (1976), 'Trade, growth and consumption in alternative models of capital accumulation', Journal of International Economics, vol. 6, issue 4, pp. 371-84.

Smith, M.A.M. (1977), 'Capital accumulation in the open two-sector economy', The Economic Journal, vol. 87, no. 345, pp. 273-82.

Srinivasan, T.N. and Bhagwati, J.N. (1980), 'Trade and welfare in a steady-state', in Chipman, J.S. and Kindelberger, C.P. (eds.), Flexible Exchange Rates and the Balance of Payments: Essays in memory of Egon Sohmen, North-Holland, Amsterdam, pp. 341-53.

Walmsley, T.L. (2002), 'Incorporating international ownership of endowments into a global applied general equilibrium model’, Economic Modelling, vol. 19, issue 5, pp. 679-707.

Willenbockel, D. (1999), 'Dynamic applied general equilibrium trade policy analysis in the presence of foreign asset cross-ownership', Economic Modelling, vol. 16, issue 3, pp. 371-88. 